\title{
Diffusjonsvektet MR
}

\section{ved transitorisk iskemisk anfall}

\author{
Bedret radiologisk diagnostikk av cerebral iskemisk skade har vært medvirkende til en moderne, vevsbasert \\ definisjon av transitorisk iskemisk anfall og hjerneinfarkt. Diffusjonsvektet magnetisk resonanstomografi har \\ høy sensitivitet og spesifisitet for infarktforandringer ved utredning av mulig cerebral iskemi. Vi mener at \\ metoden bør være en av grunnpilarene i diagnostikken av pasienter med mulig transitorisk iskemisk anfall.
}

Transitorisk iskemisk anfall (TIA) er tradisjonelt blitt definert som en episode med nevrologiske symptomer av iskemisk etiologi med varighet under 24 timer (1). Denne definisjonen stammer fra 1970-årene og var basert på en antakelse om at symptomene kun representerte noe flyktig, uten permanent iskemisk hjerneskade. På denne tiden hadde man få eller ingen diagnostiske hjelpemidler tilgjengelig for å påvise hjerneinfarkt. Ved å bruke en tidsbegrensning på 24 timer kunne man skille en antatt benign TIA-diagnose fra den mer alvorlige hjerneinfarktdiagnosen.

Siden den gang har det skjedd mye innenfor nevroradiologien. Ved hjelp av diffusjonsvektet magnetisk resonanstomografi (MR-DWI) vet vi nå at en stor andel av pasientene som tradisjonelt har fătt TIA-diagnosen, faktisk har hjerneinfarkt. Cytotoksisk ødem oppstår i løpet av minutter ved cerebral iskemi og vises som diffusjonsavvik ved MR-DWI. Der det er spørsmål om cerebral iskemi, er metoden derfor svært sensitiv allerede på et tidlig stadium (2). Studier har vist at majoriteten av disse diffusjonsavvikene representerer permanent iskemisk hjerneskade (3).

I en studie fra Haukeland universitetssykehus hvor pasienter med TIA eller hjerneinfarkt ble inkludert, viste vi at $48 \%$ av pasientene med TIA-symptomer hadde diffusjonsavvik ved diffusjonsvektet MR (4), noe som samsvarer med funn $i$ andre studier (5). Omtrent halvparten av pasientene som etter den tradisjonelle definisjonen har TIA, har altså egentlig et hjerneinfarkt.

\section{En ny definisjon}

Denne terminologiske forvirringen var bakteppet til at en ny, vevsbasert TIA-definisjon ble foreslått i 2009 (6) og senere integrert $i$ en ny definisjon av hjerneinfarkt i 2013 (7). I den nye TIA-definisjonen går man bort fra tidsaspektet på 24 timer og sier at det kun er snakk om transitorisk iskemisk anfall hvis det foreligger en reversibel iskemisk episode med nevrologiske symptomer uten radiologisk funn av hjerneinfarkt. Hjerneinfarkt inkluderer her diffusjonsavvik ved diffusjonsvektet MR.

Denne definisjonen er blitt godt mottatt av dem som mener at en vevsbasert definisjon er en riktig tilpasning $i$ forhold til definisjonene av andre iskemiske tilstander, f.eks. innen kardiologien. Noen kritiske røster har imidlertid påpekt at en slik vevsbasert definisjon vil gi ulik insidens av transitoriske iskemiske anfall og hjerneinfarkt, avhengig av den lokale tilgjengeligheten og bruken av diffusjonsvektet MR. Denne antakelsen er rent praktisk sett riktig

\section{«Diffusjonsvektet} magnetisk resonanstomografi bør gjennomføres hos alle pasienter der man mistenker transitorisk iskemisk anfall»

og stemmer overens med hva vi fant $i$ vår studie. En vevsbasert TIA-definisjon og økende bruk av diffusjonsvektet MR, fra $41 \%$ i 2006 til $90 \%$ i 2011, hos pasienter med TIA-symptomer førte til en signifikant nedgang $\mathrm{i}$ antall TIA-diagnoser og en tilsvarende økning av antall hjerneinfarkter i samme tidsrom (4).

\section{Nøyaktig diagnostikk gir riktigere behandling}

Diffusjonsvektet MR har likevel gjort mer for TIA-diagnostikken enn å skyve TIAdefinisjonen i en mer patofysiologisk korrekt retning. Transitorisk iskemisk anfall er en klinisk diagnose hvis gullstandard er begrenset til vurdering av en slagspesialist, noe som kan være vanskelig når symptomene har gått i regress og man ikke har noen objektive funn (8). Ved å øke bruken av MR i diagnostikken vil man kunne sette en sikker hjerneinfarktdiagnose på en stor del av pasientene med mistenkt TIA og dermed sikre at disse får riktig behandling.

Det er alvorlig hvis en pasient med en iskemisk lidelse feildiagnostiseres med en ikke-vaskulær tilstand og dermed ikke får korrekt sekundærprofylakse. I så fall er faren stor for at denne pasienten kan få et mer alvorlig hjerneinfarkt innen kort tid (9). Det er også uheldig om en pasient med en ikke-vaskulær tilstand får en TIA-diagnose og dermed unødvendig sekundærprofylakse, feilaktig prognostisk informasjon og forsinket behandling av den egentlige årsaken til symptomene. Sistnevnte er en relevant problemstilling, ettersom studier viser at opptil $40 \%$ av pasientene som henvises med spørsmål om TIA egentlig har en ikke-vaskulær årsak til sine symptomer, for eksempel migrene eller perifer vertigo (10).

Her mener vi at diffusjonsvektet MR vil være et uvurderlig hjelpemiddel som så å si tillater en titt i «fasiten» i de tilfellene hvor det foreligger ferske diffusjonsavvik. I disse tilfellene vet man dermed at pasienten har en iskemisk lidelse og skal behandles deretter.

Diffusjonsavvikene gir også en viktig pekepinn på etiologien bak iskemien. Spredte diffusjonsavvik over flere vaskulære gebeter tilsier en kardioembolisk mekanisme, mens et mindre diffusjonsavvik i basalgangliene tyder på småkarssykdom. Riktig valg av behandling - antikoagulasjon versus platehemming - er avhengig av denne differensieringen. Diffusjonsavvik på MR har også vist seg å ha prognostisk betydning - det er betydelig høyere risiko for nytt hjerneinfarkt der det foreligger diffusjonsavvik enn der diffusjonsvektet MR er negativ (11).

Bruken av diffusjonsvektet MR-diagnostikk varierer på norske sykehus. Det er ikke vist at metoden fører til bedre prognose hos TIA-pasienter eller ved hjerneinfarkt. Likevel har fordelene med metoden, i form av mer nøyaktig diagnostikk med tanke på symptomenes etiologi, ført til en anbefaling fra American Heart Association om at diffusjonsvektet magnetisk resonanstomografi bør gjennomføres hos alle pasienter der man mistenker transitorisk iskemisk anfall (12).

Vi mener dette er den eneste riktige tilnærmingen $i$ en tid hvor definisjonene av cerebral iskemi er vevsbasert og hvor moderne nevroradiologisk diagnostikk åpner nye dører for å oppdage iskemisk skade. Her kan diffusjonsavvik fjerne tvil hos mange pasienter som ellers ville vært ofre for vår diagnostiske usikkerhet.

Christopher Elnan Kvistad

echr@helse-bergen.no

Lars Thomassen

Gunnar Moen

Halvor Næss 
Christopher Elnan Kvistad (f. 1982) er lege og stipendiat ved Nevrologisk avdeling, Haukeland universitetssykehus.

Forfatter har fylt ut ICMJE-skjemaet og oppgir ingen interessekonflikter.

Lars Thomassen (f. 1947) er spesialist i nevrologi, med spesialkompetanse i nevrovaskulære sykdommer. Han er professor ved Universitetet i Bergen og leder Nevrovaskulær forskningsgruppe.

Forfatter har fylt ut ICMJE-skjemaet og oppgir ingen interessekonflikter.

Gunnar Moen (f. 1958) er spesialist i radiologi, med spesialkompetanse i nevroradiologi. Han er overlege ved Radiologisk avdeling, Nevroradiologisk seksjon, Haukeland universitetssykehus. Forfatter har fylt ut ICMJE-skjemaet og oppgir ingen interessekonflikter.

Halvor Næss (f. 1957) er spesialist i nevrologi og $\mathrm{i}$ indremedisin. Han er overlege ved Slagenheten, Haukeland universitetssykehus.

Forfatter har fylt ut ICMJE-skjemaet og oppgir ingen interessekonflikter.

\section{Litteratur}

1. A classification and outline of cerebrovascular diseases. II. Stroke 1975; 6: 564-616.

2. Albers GW. Diffusion-weighted MRI for evaluation of acute stroke. Neurology 1998; 51 (suppl 3): S47-9.

3. Asdaghi N, Campbell BC, Butcher KS et al. DWI reversal is associated with small infarct volume in patients with TIA and minor stroke. AJNR Am Neuroradiol 2014: 35: 660-6.

4. Kvistad CE, Thomassen L, Waje-Andreassen U et al. Clinical implications of increased use of MR in TIA. Acta Neurol Scand 2013; 128: 32-8.

5. Kidwell CS, Alger JR, Di Salle F et al. Diffusion MR in patients with transient ischemic attacks. Stroke 1999; 30: 1174-80.

6. Easton JD, Saver JL, Albers GW et al. Definition and evaluation of transient ischemic attack: a scientific statement for healthcare professionals from the American Heart Association/American Stroke Association Stroke Council. Stroke 2009 40: 2276-93.

7. Sacco RL, Kasner SE, Broderick JP et al. An updated definition of stroke for the 21st century: a statement for healthcare professionals from the American Heart Association/American Stroke Association. Stroke 2013; 44: 2064-89.

8. Castle J, Mlynash M, Lee K et al. Agreement regarding diagnosis of transient ischemic attack fairly low among stroke-trained neurologists. Stroke 2010; 41: 1367-70.

9. Pavlovic AM, Barras CD, Hand PJ et al. Brain imaging in transient ischemic attack - redefining TIA. J Clin Neurosci 2010; 17: 1105-10.

10. Martin PJ, Young G, Enevoldson TP et al. Overdiagnosis of TIA and minor stroke: experience at a regional neurovascular clinic. QJM 1997. 90: 759-63.

11. Ay H, Koroshetz WJ, Benner T et al. Transient ischemic attack with infarction: a unique syndrome? Ann Neurol 2005; 57: 679-86.

12. Jauch EC, Saver JL, Adams HP Jr et al. Guidelines for the early management of patients with acute ischemic stroke: a guideline for healthcare professionals from the American Heart Association/ American Stroke Association. Stroke 2013; 44: 870-947.

Mottatt 7.1. 2015, første revisjon 17.3. 2015, godkjent 13.4. 2015. Redaktør: Lise Mørkved Helsingen.

Publisert først på nett. 